\title{
Development of Mini Boxing Models for Early Age Athlete Coaching
}

\author{
Wijono $^{1,}$ Nining Widyah Kusnanik ${ }^{2}$ Bayu Agung Pramono ${ }^{3,}$ Eva Ferdita Yuhantini ${ }^{* *}$ \\ 1,2,3,4 Departement of Sports Coaching Education, Surabaya State University, Surabaya, Indonesia \\ ${ }^{*}$ Corresponding author. Email: evayuhantini@unesa.ac.id
}

\begin{abstract}
The purpose of this study was to develop a boxing training model for early childhood. This research is development research using Gall \& Borg. A total of 209 students aged 11-12 years, 39 teachers, three trainers, three referees, and two doctors participated in this study. Based on the analysis of the expert team, $90 \%$ of the expert team agreed on changes in facilities and infrastructure, $94 \%$ agreed on reducing the duration of each round, $87 \%$ agreed on the use of body protector, $92 \%$ agreed that there were only two types of blows. In addition, the head area was prohibited from becoming a hit target. The results of evaluations in small groups $84 \%$ agree on these changes and the results of evaluations in large groups $95 \%$ agree on changes in mini boxing matches, and it can be concluded that the mini boxing match model can be used as one of the models for the development of cognitive and motor skills in early childhood.
\end{abstract}

Keywords: Training model, Mini boxing, Early age.

\section{INTRODUCTION}

Exercise is essential for children. Regular participation in sports activities or physical activity will improve their cognitive function and body fitness [1]. Although it is essential in developing cognitive function and sports fitness must be safe for them to do. Exercise at an early age also positively affects the social environment at a young age [2]. Exercise should also have an impact on mental changes in children. Martial arts can affect a child's mental health, and these psychological changes result from the principles of the sport itself [3]. Through the sport of martial arts, children are expected to be able to increase their confidence.

The assumption that sports can improve cognitive, mental and social abilities cannot be separated from various disciplines that contribute to sports training, such as kinesiology, neuroscience, and human anatomy [4]. So it takes a proper method in the training process to realize the function properly [5]. During this time, martial arts sports such as boxing have a negative response because boxing exercises are done with no regard for the safety of athletes and followed by students as a basis for wanting to have a mere macho status [6]. Boxing is also a sport that has many injury effects [7]. Therefore, research related to the application of martial arts makes the safety aspect a top priority. On the other hand, the goal of physical contact sports is the development of cognitive abilities, and fitness can be realized. This is very appropriate to be used as a reference for the development of boxing at an early age [8].

This research concentrates on the development of mini boxing in improving cognitive and motor skills, focusing on activities that minimize the risk of injury in athletes. The development of mini boxing based on modifications in facilities and infrastructure, regulations, types, and targets of punches and accessories used by athletes needs to be done as part of the coaching of early age boxing sports to develop cognitive and motor abilities and encourage the public in utilizing the sport of boxing for sports physical activity.

\section{METHODS}

The development research model is used in this research, so the research steps according to Research \& Development research consist of 10 stages where the researcher has been modified into nine stages [9]. A total of 209 students aged $11-12$ participated in the study. A total of 47 experts consisting of 39 teachers, three coaches, three referees, and two doctors. Description of the steps in the study as follows: 


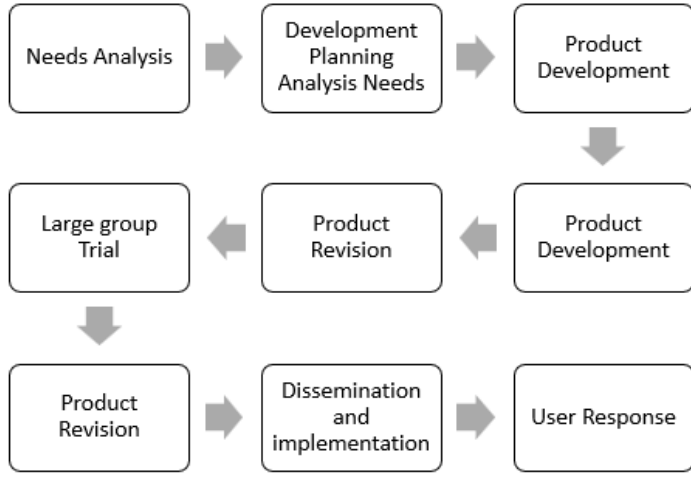

Figure 1. Modified Gall \&Borg Development Procedure

Need assessment through the dissemination of questionnaire questionnaires to 209 students of SDN Sananwetan III Blitar and Al Falah Surabaya Elementary School and 39 physical education teachers. The second stage planned the manufacture of model products to change the size of the boxing ring area, changing the time rules, changes in the regulation of punch type, changes in target punches, and accessories used - the third stage of the development of the initial product based on the results of the needs analysis. In the fourth stage of tries, the initial product is assessed by experts consisting of 10 students of Sanan Wetan III Elementary School Kota Madya circuit randomly, four physical education teachers, three amateur boxing coaches (certified regional boxing coach), three boxing referees amatir (certified referee/judge boxing two regions, 1 level east java team)and two doctors (1 doctor Pertina Jatim and one doctor pertina circuit). The fifth stage of the trial results in a small group then improved to perfect the trial results. Finally, the Sixth Stage tried the revised product in a large group, namely on 40 students of Sanan Wetan III Elementary School., 15 teachers of physical education of Blitar city, three amateur boxing coaches (certified regional boxing coaches), three boxing referees amatir (certified referee/judge boxing two regions and 1 level east java) and two doctors ( 1 doctor pertina east java and one doctor pertina blitar). The seventh stage of the utilization of the product results of the trial in a large group. The eighth stage of seminars and product implementation includes boxing match activities in east java and mini boxing exhibitions and the provision of workshops - ninth stage Mini first user response by the user via questionnaire data.

The results of calculating data that have been obtained using descriptive statistics are referenced in the criteria in table 1 so that the feasibility of mini boxing development can be known. Data in percentages, proportions, and ratios, then later conclusions will be drawn [10].

Table 1. Eligibility Category

\begin{tabular}{|l|l|l|}
\hline Category & Percentage & Information \\
\hline Good & $76 \%-100 \%$ & Used \\
\hline Enough & $56 \%-75 \%$ & Used \\
\hline Less Good & $40 \%-55 \%$ & Not Used \\
\hline Bad & Less than $40 \%$ & Not Used \\
\hline Good & $76 \%-100 \%$ & Used \\
\hline
\end{tabular}

(Arikunto, 2010)

\section{RESULTS}

The First Stage is the presentation of data from the needs analysis. The results of the needs analysis questionnaire can be seen in table 2 . Table 2 explains that more than $76 \%$ of students and teachers understand the sport of boxing. However, more than $71 \%$ of students and teachers say boxing is a dangerous sport. So that more than $84 \%$ of students and teachers want modification on the implementation of the sport of boxing.

Table 2. Presentation of Need Analysis Data by 209 students and 39 teachers

\begin{tabular}{|c|c|c|}
\hline No. & Component & Result \\
\hline 1 & $\begin{array}{l}\text { Analysis of students' needs } \\
\text { through charging questionnaires }\end{array}$ & $\begin{array}{l}\text { 1. } 76 \% \text { of students understand the sport of boxing } \\
\text { 2. } 71 \% \text { of students consider the sport of boxing very dangerous } \\
\text { 3. } 84 \% \text { of students want modifications to the sport of boxing }\end{array}$ \\
\hline 2 & $\begin{array}{l}\text { Analysis of The Teacher's } \\
\text { needs through filling the } \\
\text { questionnaire }\end{array}$ & $\begin{array}{l}\text { 1. } 85 \% \text { of sports teachers know about the sport of boxing } \\
\text { 2. } 76 \% \text { of sports teachers consider boxing to be very dangerous } \\
\text { 3. } 96 \% \text { of sports teachers want there to be modifications to the sport of } \\
\text { boxing }\end{array}$ \\
\hline
\end{tabular}


Table 3. Presentation of Evaluation Data by a Team of Expert on Mini Boxing Development

\begin{tabular}{|c|c|c|}
\hline No. & Component & Result \\
\hline 1 & Evaluation of Facilities and Infrastructure & $\begin{array}{l}\text { 1. } 90 \% \text { of the expert team agrees on the change in } \\
\text { facilities and infrastructure, namely changing the size } \\
\text { of the boxing ring to } 4 \times 4 \text { meters from its actual size } \\
\text { of } 4.9-6.1 \text { meters and the giving of a boundary line } \\
\text { used as a stop sign line should not go out of line. This } \\
\text { is done to familiarize athletes at the junior stage is used } \\
\text { to not playing touching the ring because it results in a } \\
\text { referee's reprimand that will affect the value of the } \\
\text { match. }\end{array}$ \\
\hline 2 & Evaluation rule change & $\begin{array}{l}\text { 1. 94\% of expert teams agree on reducing the duration and } \\
\text { rounds used, which is } 1 \text { minute } 30 \text { seconds per round, } \\
\text { and the number of rounds to } 3 \text { rounds and } 1 \text { minute for } \\
\text { rest. In addition to reducing the risk of injury as a time } \\
\text { control for physical fatigue due to carrying out boxing } \\
\text { activities exceeding the threshold of the training zone. }\end{array}$ \\
\hline 3 & Evaluation of the use of body protectors & $\begin{array}{l}\text { 1. } 87 \% \text { of the expert team as well as the use of body } \\
\text { protector as a protector on the chest because as a target } \\
\text { of blows, Head guard on the head, added mouth guard } \\
\text { dental protector as reduce impact and risk the wrong } \\
\text { target blows on the head, cup protector on the pubic } \\
\text { and glove (boxing gloves) is mandatory equipment } \\
\text { that must be worn with a weight of } 8 \text { ounces and } \\
\text { bandage (hand) before wearing boxing gloves to avoid } \\
\text { injury to the fingers and wrists. }\end{array}$ \\
\hline 4 & Evaluation of targets of blows & $\begin{array}{l}\text { 1. } 92 \% \text { of the team of experts agreed to change and deal } \\
\text { with the type of punch and the target of a legitimate } \\
\text { punch on the target where there are only two types of } \\
\text { punches, namely jab and straight, while the hook and } \\
\text { uppercut punches are prohibited. The head area is also } \\
\text { a forbidden area to be targeted by blows. Athletes who } \\
\text { make mistakes three times will experience a reduction } \\
\text { of points to disqualification if a blow is intentional on } \\
\text { the head target. This change will lead to injury. }\end{array}$ \\
\hline
\end{tabular}

Table 3 presents an evaluation of the development of mini boxing by a team of experts, and four main parts must be modified, namely facilities and infrastructure, regulations, other use of body protectors, and the type/target of punches. The results of Modi's evaluation of the four components of more than $87 \%$ of the expert team approved of the change. The purpose of this change is to provide security for athletes who will compete.
Table 4 presents the results of mini boxing testing on small groups and large groups. In table 4, socialization factors become essential factors in the successful implementation and implementation of mini boxing. There needs to be regular education so that athletes, coaches, and teachers understand the difference. 
Table 4. The results of mini boxing testing

\begin{tabular}{|c|c|c|}
\hline No. & Component & Result \\
\hline 1 & $\begin{array}{l}\text { Trial on Small Group of } 10 \\
\text { students of Sanan within III } \\
\text { Elementary School blitar } \\
\text { municipality, four teachers, three } \\
\text { coaches, three referees, and two } \\
\text { doctors. }\end{array}$ & $\begin{array}{l}\text { 1. The trial results in a small group obtained } 84 \% \text { of students, teachers, } \\
\text { and expert teams consisting of coaches, referees, doctors, and the } \\
\text { results of the changes. This change protects athletes from injury } \\
\text { despite the need for continuous socialization to reduce blow injuries } \\
\text { to the head area. }\end{array}$ \\
\hline 2 & $\begin{array}{l}\text { Trial on Besa Group } 40 \\
\text { elementary school students of } \\
\text { Blitar city, four teachers, three } \\
\text { coaches, three referees, and two } \\
\text { doctors. }\end{array}$ & $\begin{array}{l}\text { 1. The trial results in a large group obtained } 95 \% \text { of students, teachers, } \\
\text { and expert teams consisting of coaches, referees, doctors, and the } \\
\text { results of the changes. Trials in large groups gave better results } \\
\text { because it was done two months after the first trial so that the } \\
\text { socialization of mini boxing was much better, blows to the head were } \\
\text { reduced drastically. In addition, athletes began to understand the rules } \\
\text { on the development of mini boxing. }\end{array}$ \\
\hline
\end{tabular}

Figure 2 showed there was a change in the percentage of user response and expert teams on the results of mini boxing development products in children. The results of trials in small groups to large groups more than $84 \%$ agreed on the products produced so that the implementation of mini boxing by changing the size of the facilities and infrastructure, regulations, the use of body protectors, and types of punches and punch targets can be accepted by school children, teachers, coaches, referees, and team doctors.

Mini Boxing Development Product Trial for Elementary School Children

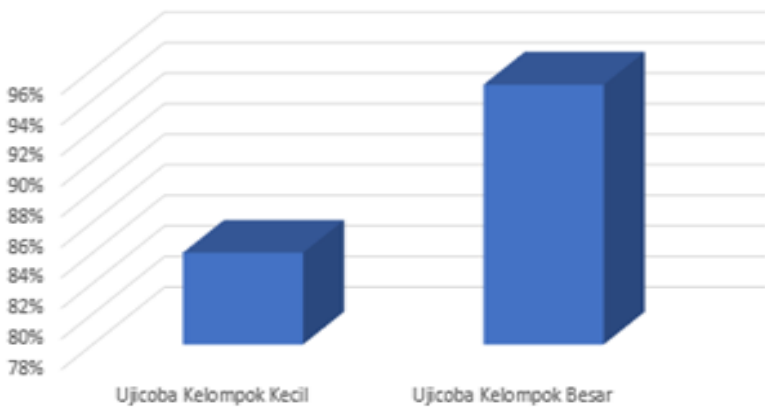

Figure 2. Trial of This Tinju M Development Product in Elementary School Children

\section{DISCUSSION}

Boxing is a martial arts sport, and this sport has a high level of injury risk due to physical contact made by athletes. Nevertheless, the sport of boxing must be developed to positively affect the pattern of coaching the sport of boxing that starts at an early age.

Exercise, in general, has a positive impact on biomotor, psychological, physiological, and sociological development. Boxing or other martial arts sports also positively impact when applied the suitable safety patterns [8]. Mini boxing is the development of boxing by paying attention to the changes of 4 components.

The four components developed in mini-boxing in this study are fundamental changes in regulations, facilities, and infrastructure, body protectors, changes in punch targets, and restrictions on punch techniques used. The rule used in mini boxing is a mini boxing match using three rounds where each round is limited to a game duration of 1 minute 30 seconds with a break of 1 minute. The boxing ring used uses a size of $4 \times 4$ meters with the addition of a boundary line on each side. Exiting the boundary line will result in a reprimand from the referee, if done up to 3 times, will be sanctioned for the distribution of points by 1 point.

Players are required to use head protection, dental protection, and chest protection to vital areas. The use of gloves weighing 8 ounces becomes an obligation that must be fulfilled [11]. Explaining the lower limit of glove weight to reduce the impact of a punch is $2.7 \mathrm{oz}, 4.5 \mathrm{oz}$, or in the bag. The use of a body protector will reduce the risk of injury to athletes [12]

The target of the blow is also determined, i.e., the chest area is protected with a body protector. A blow to the head area will result in disqualification. Strengthening of the head area will increase the high risk of head injury [13]. The head is a part of the body that often suffers minor to severe injuries such as Parkinson's in boxing athletes [14]

To reduce injuries, the type of blow that should be used an only jab and straight punches. Hook and uppercut punches do not enter the recommended type of blow because I have the fastest punch speed of 11.95 $13.79 \mathrm{~m} / \mathrm{s}$ resulting in a reasonably hard impact [15].

\section{CONCLUSION}

Based on the study results, mini boxing models were obtained by modifying facilities and infrastructure, body 
protectors, changes in regulations, and the selection of legitimate punch types and targets in the sport of mini boxing. So, it can be concluded that the mini boxing model can be accepted by students, teachers, coaches, referees, and doctors as a sport that deserves to be contested and taught in early childhood for improved cognitive and motor skills.

\section{REFERENCES}

[1] I. Bidzan-Bluma and M. Lipowska, "Physical activity and cognitive functioning of children: A systematic review," Int. J. Environ. Res. Public Health, vol. 15, no. 4, pp. 1-13, 2018, doi: 10.3390/ijerph15040800.

[2] L. Bakken, N. Brown, and B. Downing, "Early Childhood Education: The Long-Term Benefits," J. Res. Child. Educ., vol. 31, no. 2, pp. 255-269, 2017, doi: 10.1080/02568543.2016.1273285.

[3] B. Moore, D. Dudley, and S. Woodcock, "The effects of martial arts participation on mental and psychosocial health outcomes: A randomised controlled trial of a secondary school-based mental health promotion program," $B M C$ Psychol., vol. 7, no. 1, pp. 1-7, 2019, doi: 10.1186/s40359-019-0329-5.

[4] M. Alesi et al., "Motor and cognitive development: the role of karate Corresponding author :," Muscles Ligaments Tendons J., vol. 4, no. 2, pp. 114-120, 2014.

[5] M. Theeboom, P. De Knop, and J. Vertonghen, "Experiences of children in martial arts," Eur. $J$. Sport Soc., vol. 6, no. 1, pp. 19-34, 2009, doi: 10.1080/16138171.2009.11687825.

[6] D. Endresen, I. M., \& Olweus, "Participation in power sports and antisocial involvement in preadolescent and adolescent boys.," J. Child Psychol. Psychiatry Allied Discip., vol. 46, no. 5, pp. 468-478, 2005, doi: https://doi.org/10.1111/j.14697610.2005.00414.x.

[7] G. H. Bledsoe, G. Li, and F. Levy, "Injury risk in professional boxing," South. Med. J., 2005, doi: 10.1097/01.smj.0000182498.19288.e2.

[8] C. Rasmussen, S. Diekmann, C. Egan, T. Johnson, and F. X. Shen, "How Dangerous Are Youth Sports for the Brain: A Review of the Evidence," Berkeley J. Entertain. Sport. Law, vol. 7, no. 67, p. 81, 2018.

[9] M. D. Gall, J. P. Gall, and W. R. Borg, Educational Research: An Introduction, eighth Edition, Seventh Ed. United States: Pearson Education, 2003.

[10] S. Arikunto, Prosedur Penelitian Pendekatan Praktik Edisi Revisi VI. In Rineka Cipta. 2010.
[11] P. Perkins, A. Jamieson, W. Spratford, and A. Hahn, "Evaluation of Ability of Two Different Pneumatic Boxing Gloves to Reduce Delivered Impact Forces and Improve Safety," World J. Eng. Technol., vol. 06, no. 02, pp. 457-491, 2018, doi: 10.4236/wjet.2018.62028.

[12] Y. R.. Andres, S. A., Bushau-Sprinkle, A. M., Brier, M. E., \& Seger, "Effects of body protection vests and experience levels in prevention of equestrian injuries," BMJ Open Sport Exerc. Med., vol. 4., no. 1, pp. 1-6, 2018, doi: https://doi.org/10.1136/bmjsem-2018-000426.

[13] M. R. Graham et al., "Direct hits to the head during amateur boxing is associated with a rise in serum biomarkers for brain injury," Int. J. Immunopathol. Pharmacol., vol. 24, no. 1, pp. 119-125, 2011, doi: $10.1177 / 039463201102400114$.

[14] M. Loosemore, J. Lightfoot, and C. Beardsley, "Boxing injuries by anatomical location: a systematic review," J. Rom. Sport. Med. Soc., vol. XI, no. 2, pp. 2583-2590, 2015.

[15] E. Stanley, E. Thomson, G. Smith, and K. L. Lamb, "An analysis of the three-dimensional kinetics and kinematics of maximal effort punches among amateur boxers," Int. J. Perform. Anal. Sport, vol. 18, no. 5, pp. 835-854, 2018, doi: $10.1080 / 24748668.2018 .1525651$. 